\title{
Prospects for European and Eurasian Security and China's Future Choices
}

\author{
Shaolei Feng ${ }^{1}$
}

Received: 16 April 2016/Accepted: 7 September 2016/Published online: 3 November 2016

(C) Fudan University and Springer Science+Business Media Singapore 2016

\begin{abstract}
The escalating crisis and ever changing developments in Ukraine and Syria have sparked widespread concern in China and among the international community at large. What are the security prospects confronting Europe and the Eurasian region? This paper will illustrate the current developments and future outlook of these regions by studying diachronically how Europe and the Eurasian region have been changing geopolitically and economically over the years, the trilateral relationship between Russia, US and China, as well as China's reaction towards it.
\end{abstract}

Keywords European and Eurasian security - China's future choices - Trinity perspective

\section{Geopolitical and Economic Competition between Russia and the West in the New Century}

After the collapse of the Soviet Union, the all-out strategic confrontation between the Soviet Union and the West was brought to an end. Russia, while ushering in a market economy and political democracy domestically, tilted its foreign policy towards the West at one point. However, the so-called "honeymoon" period did not last long, with a recurrence of the trouble-ridden relationship between Russia, US and Europe following shortly afterwards.

Shaolei Feng

shaoleifeng@yahoo.com; slfeng@dlps.ecnu.edu.cn

1 School of Advanced International and Area Studies, East China Normal University, Shanghai, China 


\subsection{Geopolitical Patterns From Detente to Confrontation}

The Russian strategist Sergei Karaganov once argued: there have been no fatal security threats from the West to the Soviet Union since the 1970s. The reason for the collapse of the Soviet Union was mostly domestic (Karaganov 2011). According to the Russian Federation's foreign policy published in February 2013, although international politics is currently in transition and prospects for development are increasingly unpredictable, the "ability of the West to dominate world economy and politics continues to diminish. The global power and development potential is now more dispersed and is shifting to the East, primarily to the Asia-Pacific region". ${ }^{1}$ In this argument, the US and Europe have not been perceived by Russian elites as the primary rivalry posing fatal geopolitical threats to Russia for long time, a drastic contrast to the perception held by the Soviet Union towards the US and Europe back in the early years of the Cold War.

However, from a strategic competition standpoint, the competition between Russia and Western countries led by the US and Europe, never seemed to cease. With successive outbreaks of hot-spot conflicts, this latent competition is shaping into a more blatant one. The 2013 Ukraine crisis is an ostensive proof of the confrontational tension between Russia and the West.

Globally speaking, Russia strongly opposes American hegemony and advocates multipolar politics as a balanced new international order. Russia tries hard to promote integration between emerging countries, especially cooperation between BRIC nations. Despite recent lagging behind in a few emerging countries, general prospects look consistently promising. Russia not only has the vastest territory, but also is reputed to be one of the two nations with the strongest military power in the world. Russian energy advantages still have far reaching influence that knows no geographical boundaries. Russia is also known for its skill and huge potential in many hi-tech industries. All of the above resources have laid a firm foundation for Russia to wield influences across the borders. Regrettably, the challenges and obstacles facing Russia have belittled its power. This is one of the problems for US and European strategy towards Russia.

Regionally speaking, first of all, the US antimissile system in Central Eastern and Southeast Europe has weighed heavily on Russia, a situation that has been further consolidated after the Ukraine crisis. This is the Sword of Damocles hung high on Russia's borders. Secondly, the former Soviet Union region, which Russia has referred to as the place where its special influence can be displayed, especially in Georgia and Ukraine, is still under the wings of the US and Europe, containing Russia's ambition of reviving its economic and political clout in this region. Thirdly, the military presence and influence of the US and European countries in Central Asia and Afghanistan are perceived by Russia as the prelude to a geopolitical competition with the West. The West is interpreted to be targeting directly at the core of the Commonwealth of the Independent States. Fourthly, in

\footnotetext{
${ }^{1}$ Concept of the Foreign Policy of the Russian Federation, February 18th 2013, Approved by President of the Russian Federation V. Putin. http://www.mid.ru/en/foreign_policy/official_documents/-/asset_ publisher/CptICkB6BZ29/content/id/122186.
} 
places where political and sectarian conflicts abound such as Syria and Iraq, Russia has wiggle room to intervene. Even if the Iran nuclear problem gets solved eventually, it is still far from the end of competition between big powers in the Middle East and West Asia. Under this complicated domestic and international milieu, Russia still has huge influence over Middle East and North Africa. In the end of September 2015, Russia is well poised to wage an air strike against "Islamic State" in Syria, ostensive proof of Russia's power in these regions.

On the whole, the strategic competition between Russia and the West is no longer the all-out military confrontation it once was in the Cold War era, which was based on the old notion of ideology with both sides relying on alliances between nation states, and featuring the nuclear Balance of Terror. It also does away with the cruelty of the zero-sum game. However, the tension still remains. The crisis in Ukraine and Syria indicates the intense conflict between Russia and US in terms of ideology, strategic and security interests. The existence of NATO has once again become a primary threat to Russia's security.

From the perspective of the strategic security relationship between Russia and Europe, before the financial crisis, with temporary suspension of the eastward expansion of NATO and Europe, Western-Russian geopolitical competition remained tame. Despite the five-day war between Russia and Georgia and the heated debate that followed, Russia and the West remained on good terms with each other after some intermediation. In spite of the emergence of the shale gas revolution, Europe still heavily maintained its close energy cooperation with Russia. In this light, the mutually dependent relationship between Russia and Europe, that is built on traditional political, economic, energy cooperation and people-to-people exchange, continues to play an important role. There is no dramatic change happening to the bilateral relationship.

However, after 2009, as the international political competition began shifting its dimension from a global one to a more regional one, the two regional integration mechanisms, namely the EU "Eastern Partnership" and the Russian "Eurasian Union", both of which are targeted at the Eurasian region but come from opposite directions and have intense rivalry, lead to acute conflict. This is also the direct trigger of the Ukraine crisis. Meanwhile, cavernous cracks emerged in the mutually dependent relationship in energy and commodity markets between Russia and the EU, and their bilateral political relationship was also on the brink of collapse. Despite constant efforts from the EU and Russia since the crisis began to mitigate the conflict, the Ukraine crisis remains reluctantly unsolved in the complicated context of this region.

\subsection{Geopolitical Competition Intertwined with Domestic and Foreign Politics}

Since the financial crisis, generally speaking, the relationship between Russia and the US and EU has found it difficult to improve due to the confinements of historical logic. This historical logic appears in periodic pattern, intertwined with domestic and foreign politics. In this light, in the thirty years after the mid 1980s, the 
relationship between the Soviet Union/Russia and the US and EU has followed a process of adjustment-confrontation-readjustment-re-confrontation.

When Mikhail Gorbachev came into power, under the backdrop of reform, he set forth his regime on the task of improving the relationship with the West. However his 6-year administration was ill fatedly hit with the final collapse of the Soviet Union, during which neither the EU nor US offered tangible help. Both Soviet elites and the general public were greatly disappointed. During Boris Yeltsin's regime, though it set off with a one-sided pro-Western policy both domestic and foreign, it ended up with nearly direct military conflicts between Russia and the West in the Kosovo War. During President Putin's reign, the rapport with the West was writ large from the outset. This is especially true when under the backdrop of 9.11, Mr. Putin offered an olive branch to the West by opening access for the US to Russia's strategic military passage and allowed their deployment in Russia's military base. Despite that, in the end of Mr. Putin's second term, heated discussion about the "Russia-Georgia war" between Russia and the West flared up. Within less than 30 years, there was a clear periodical pattern-friendly first and confrontational next - that kept reemerging in the way three Russian presidents dealt with the West.

Understanding why there is such periodical tension between the two requires attention not only to the difficulty in mediating this relationship, but also to Russia's internal system, which has been a focal point of division. In the beginning of Mikhail Gorbachev's regime, he started off by reform, promoting political diversity and democracy. However, after 6 years' administration, Mr. Gorbachev decided to combine the post of Soviet Communist Party general-secretary with Soviet Union President. From a Western perspective, it was tantamount to the revival of centralization. When Boris Yeltsin came into power, under the context of that period, he prioritized implementing political democracy and decentralization of the market economy in his political agenda. However, in the second half of 1990s, Russian politics began tilting towards family hierarchy and oligarchy, which also infuriated the West. In President Putin's period, Mr. Yeltsin's political legacy was maintained at the outset. However, after 2003, he denied access to direct suffrage for local governors and put the lid on private capitalists' intentions to monopolize national strategic capital. In the meantime, he ganged up with France and Germany to oppose the Iraq War initiated by the US. Later on, he began tightening domestic politics. These reasonable adjustments in response to the transformation in the 1990s were perceived by the West as the revival of the old "Soviet Union system".

By observing Mikhail Gorbachev, Boris Yeltsin and Putin's successive deadlocks with the West, it can be concluded that the changes in Russia's internal political system remain the key reason for the deterioration of its relationship with the West.

In short, there are too many historical intricacies between Russia, Europe and the US that cannot be explained in words. The impact of ideological division is hardly insignificant in the bilateral relationship. In addition, over 20 years of tit for tat, including geopolitical fights over power and rights, have made it difficult for a congenial friendly strategic partnership to take shape between Europe and Russia. Furthermore, the striking division over what Russia's political system should look like during the transitional period sparked off heated debates and even direct confrontation, to which the continuous crises in Ukraine and Syria are a testament. 


\section{The Trilateral Relationship: from the Ukraine Conflict to the Syrian Crisis}

Since the Cold War, Russia has maintained a trilateral dynamism with the US and Europe.

Whether the three parties are in harmony or in discord has a big impact on the relationship between Russia and the West. In other words, when there are conflicts between the US and Russia, whether Europe can mediate or not will have a significant impact on the situation; and when the US-EU relationship remains stagnant, whether the US and Russia can see some improvement will greatly help the relationship between Russia and the West. In short, the trilateral interaction between the US, Russia and Europe has significant impact on the bilateral relationship between Russia and the West.

This trilateral dynamism exists not only in international organizations that have a specific purpose like the Organization for Security and Co-operation in Europe (OSCE) and the G8, it also exists as a multilateral platform in response to major events, like the 6-party mechanism for the Iran nuclear issue, the Normandy Mechanism for the Ukraine issue as well as the Geneva mechanism in Syria, etc. Of course, the UN General Assembly and other global platforms are the primary frameworks where the three parties interact with each other. On the other hand, Russia, the US and Europe will also interact actively in addressing problems that occur bilaterally, regionally and globally. In this trilateral relationship, the most important one to date in the world, is that they both fight and cooperate with each other and are constantly seeking new patterns of coexistence.

On the whole, in the 20 years of the post-Cold War era, the first 10 years saw a clear pattern in the trilateral relationship between Russia and EU and US, namely a cooperative relationship between the three. And there was not much difference between the US-Russia relationship and the EU-Russia relationship. However, at the end of Boris Yeltsin's reign when the Kosovo War took place, the relationship between Russia and the West began to sour. Russia's affinity towards the US tumbled drastically.

In the first decade of the new century, namely of the Putin regime, a series of successive events relevant to the trilateral relationship took place: $9 / 11$ in 2001; the Iraq War in 2003; the Color Revolution in 2004, the concurrent eastward expansion of the EU and NATO; the natural gas dispute between Russia and Ukraine in 2006; the Russia-Georgia war in 2008; the financial crisis of 2008, and serious, significant changes in the international governance order. Most recently, we witness the "Arab Spring", the Ukraine crisis, and the Syrian Crisis.

When taking a retrospective look at history, it is safe to say that compared to the US, Europe has more of a rapport with Russia while the US is more tough and estranged from Russia. Despite the stagnant relationship between Russia and Europe around the financial crisis, the US reversed its attitude to resume its relationship with Russia after 2009. However, that recovery did not last long and did not change the fundamental norm where Europe is more congenial with Russia while the US- 
Russia relationship is stiffer. The overall dynamic between the three parties is in line with their economic, trade, political and security power.

Since the Ukraine conflict in 2013, including in the Syrian crisis period that predates and continues to intertwine with the Ukraine crisis, Russia, the US and Europe have been in close interaction with each other. Two patterns unfolded in this trilateral relationship: one in the trilateral relationship between Russia, the US and Germany, the leading country of the EU; the other in the trilateral relationship between the Russia-led Eurasian Economic Union, the EU and NATO. This paper will focus on explaining the former.

For the moment, Germany claims dominance in Europe. This is not only because of Germany's exceptional role in leading the whole EU out of the woods in 2008 European debt crisis, but also because ever more increasingly, compared with other old powers in Europe, Germany is unparalleled in drafting Europe's strategic thinking and creating blueprints for the region. Germany is mostly concerned with the future direction of EU integration, including the "Eastern Partnership" scheme. They are especially concerned with the reaction of Eurasia, its nearest neighbor, towards this scheme. After all, when the eastward expansion reaches Kiev, Germany would be the biggest stakeholder. Inside Germany itself, despite heated debate, the center right wing led by Prime Minister Angela Merkel, by virtue of the coalition government, had successfully transformed the socialist democratic party, who were supposed to be the outside opposition, into a cooperator inside the government system. Through this, they claimed dominance in internal affairs. And after spring 2014, Germany's intention to claim leadership in EU affairs is becoming increasingly evident. In this context, Germany joined hands with the US to promote the Transatlantic Trade and Investment Partnership (TTIP) negotiations and to strengthen the bilateral relationship on the two sides of the Atlantic. On the other hand, in the infancy of Ukraine crisis, Angela Merkel bucked the trend by suppressing Russia under the premise of maintaining mediation and negotiation, instead of going the traditional pro-Russia route as her predecessors did. She stirred up intensive criticism towards Russia in the Malaysian Airline tragedy in July 2014. However as the Ukraine crisis became more complicated by the day, risks were mounting. This has become more true since the emergence of the "Islamic State". After early 2015, Germany joined hands with France and increased their engagement in the Minsk mechanism to solve the Ukraine crisis. Since then, tensions in east Ukraine have abated. Other testaments to Germany's peace-making efforts as a major mediator include: the ceasefire agreement and the withdrawal of the mass weapons agreement in eastern Ukraine after fall 2015; as well as the consensual agreement over the delay of the referendum in eastern Ukraine. Merkel emphasized that there is no connection between the Syrian crisis and Ukraine conflict. However, how can these two conflicts in such close proximity have no bearing on each other? This is only Merkel's own interpretation. The key thing is that Germany has all too often shown favor towards the US while Russia-EU relationship is left in imbalance, which makes this trilateral relationship vulnerable to a possible overturn.

Some would argue, in terms of the Ukraine crisis, that the most important competing rivalry is that of Russia and the US. The seasoned theorist and the 
advocator of "Russian authoritarianism" Andranik Migranya presented this argument long ago. ${ }^{2}$ According to him, everything concerning the Ukraine conflict depends on the bilateral relationship between the US and Russia. The only super power in the world so far, as said by President Obama, will at least "lead the world for another 100 years". Hence it is unlikely that the US will be left out of European and Eurasian affairs. Besides, during the Ukraine crisis, the opportunities brought about by the shale gas revolution have propelled the US to eclipse others in the Western world in terms of economic performance. This is the key stake the US holds in this crisis. The aforementioned context has meant America is itching to provide offensive weapons to Ukraine. Besides, from the standpoint of current American internal politics, whoever gets elected in the end (Obama thinks the likelihood that pro-Russia Trump will succeed is small) will display a tougher stance towards Russia than Obama did. On the flip side, in today's world, even though Russia is no longer the formidable rival of the US they once were back in the Cold War, they still possess a series of "silver bullets" that could pose a headache for the US. For the moment, only Russia, its age-old rival, dares to challenge the US head-on. In this light, there are some merits in the argument that only Russia and the US will be the final troubleshooters. Based on what has happened in 2015, President Obama still perceives Russia as equally evil as Ebola and Islamic State. Under heavy domestic pressure, it is unlikely that President Obama will eventually be able to negotiate a consensual peaceful resolution with Russia. The problem is that President Obama has incurred criticism for his strategic failure in his action in Syria. Especially after what had happened on September 30th 2015, when Russia seized the opportunity to attack Islamic State effectively, which ended up forcing the US to come to the negotiation table with Russia on the Syrian military issue. At the same time, the US had to cease its military training of the opposition parties and had to witness Russia and the Assad regime implementing anti-terrorism cooperation. The truth has taught us that it is the existence of terrorist groups that serves as the major motivation for the US and European approach towards Russia, albeit reluctantly.

The more important player is still Russia. Since the Ukraine crisis, despite the heavy economic burden and political pressure, Russia never displayed any concession on the Ukraine issue. Neither was Russia a small state that would easily fall victim to adversities, nor was Putin a person to be trifled with. After a year-long dire crisis as complex and tough as it was, especially with tumbling energy prices, a heavily devalued rouble, and stiff western sanctions and verbal bashing, Putin's approval rating was still as high as $80 \%$, which was a remarkable record for a big nation such as Russia. It has been predicted that under this heavy pressure, Russia is likely to face the same massive demonstration trend that occurred in Bologna in 2012. However, after the 2015 new-year holiday, a number of prestigious sociologists from both home and abroad gathered together to discuss affairs of the state. They concluded that Russia might readopt a "fortress mentality" under heavy external pressure, to fend off outside interventions and preserve the leader's authority. Sociologist Mikhail Dmitriev, who had accurately predicted the Bologna event, also made his judgment: this time is

\footnotetext{
${ }^{2}$ Speech delivered by Andranik Migranya at the panel regarding the Ukraine crisis at the 11th Valdai Club Annual Meeting in Sochi, Russia. October 24th 2014.
} 
different from the internal political competition that occurred in 2012. It will take a few years before we experience the protest storm, if there is any. There is a sufficient degree of consensus within Russia; while the US and Germany, especially since the situation in Syria escalated, are more prone to seek compromise from Russia on the one hand and maintain high pressure on the other. Early in spring 2015, the visit of Secretary of State John Kerry and Assistant Secretary of State Victoria Nuland was an ostensive testament to this.

In a nutshell, during the Ukraine and Syria crisis, the trilateral relationship between Russia, the US and Germany has maintained the same conventions that have been followed since the beginning of the new century. Germany continued to soften its tone by seeking compromise from Russia, despite an interval where the relationship soured for a time. As far as the US is concerned, as long-term historical rivals, they tried to maintain a high-hand, coercing Russia to give in. However, when Islamic State suddenly emerged, the US was caught off guard when Russia seized the opportunity to bombard it with several rounds of air strikes. Russia's "preemptive defense" strategy had left the US and Europe no choice but to come back to the negotiating table, albeit reluctantly.

\section{The Root Causes of the Escalation of Tensions in the Relationship between Russia and the West}

The crisis in Ukraine continues to drag on without a proper resolution, alternating between long periods of fighting and brief ceasefire. There is a series of deep-rooted causes behind this.

Since the Ukraine crisis, all attention has centered on the annexation of Crimea by Russia, which was widely perceived as the violation of the integrity of a nation state's sovereignty and territory. Generally speaking, this is indeed an important aspect of today's international politics that should not be neglected. This is especially true for emerging countries, for whom territorial and sovereign integrity is the root of a safe and secure existence. It is worth noting that in the post-Cold War international political milieu, this is not the first time a nation state's sovereignty and territory has been violated. The not-to-be-repeated mistake by the Western world in the Kosovo region is a case in point, namely Kosovo's independence from Socialist Federal Republic of Yugoslavia (SFRY). If the international community intends to put heavy pressure on Russia with respect to Crimea; then how will the Kosovo issue be put into perspective? Although there are some differences between the two, the fundamental principle these two cases touch upon is pretty much the same. Hence, protecting territorial and sovereign integrity is the international law that should be observed by all. The resolution of the Crimea issue requires political negotiation and proper settlement that takes into account the specific historical context. President Putin has spoken highly of China's stance towards Crimea. ${ }^{3}$

\footnotetext{
${ }^{3}$ Putin thanks the leadership of China and India for the understanding of the position of the Russian Federation, March 18th 2014. RIA Novosti. http://ria.ru/world/20140318/1000041857. html\#ixzz3oc5jas7g.
} 
At the Valdai Discussion Club Annual Meeting on October 24, 2014, President Putin delivered a speech. His answer to a question raised by the Financial Times is something worth chewing on. The question was: "do you think Ukraine is a united country in reality?" He said: "Ukraine is definitely a united country. However, the history of how its territory came to be united is rather long and complicated". Mr. Putin did recognize the importance of the integrity of a nation state's sovereignty and its territory. What he said is, for a specific country, the establishment of sovereignty is a historical process. Under the special context of the collapse of the Soviet Union in 1991 and Ukraine coup in 2014, its complexity needs to be addressed properly. ${ }^{4}$

Another point of contention that received much attention at the 2014 Valdai discussion is that the West lashed out at Russia for flip flopping the 1994 Budapest agreement they signed to acknowledge the border of Ukraine. Russia responded by saying that in the early 1990s, the West promised more than once that they have confirmed the boundaries of Russia's influential territory in the former Soviet Union area. However, the West keeps breaching their promise through ceaseless NATO and EU expansion. We can conclude: the problem does not merely rest on whether to set out the political borders of Ukraine. It should be traced back to the end of the Cold War and how the US and Soviet Union made compromises and finally reached a consensus. Is it that there is no winner in the game, which means Russia can stand on a equal footing with the West; or is it "winner takes all", which means the US and Europe have unlimited rights to expand?

Between Russia and the West, it is not just about geopolitical competition; it is more about whether two sides are willing to respect the other and bury the hatchet. At the 2014 Valdai discussion, Mr. Putin recalled a story about Russia and the US. In 2001, there was a possible cooperation opportunity between Russia and the US. Back then, Russia was willing to offer an olive branch by offering access to the mid Asia strategic area in an effort to help the US to fight against terrorism. However, in 2002, the US unilaterally quit the US-Russia "antimissile agreement" in return.

Mr. Putin made it crystal clear in the discussion: American sabotage of the Russia-US relationship started from the unilateral exit from the antimissile agreement in 2002. One can easily associate this with the Sochi Winter Olympics, which Mr. Putin had invested heavily in, in an effort to reshape the West's attitude towards Russia and do away with their prejudice. However, the collective boycott from the Western leadership had significantly bruised Russia's ego. As is said by Jack Matlock, the last US ambassador to the Soviet Union, in his article after the Ukraine crisis: it is America's arrogance that has led to Russian's reactions. ${ }^{5}$

The sticking point in the Russia-West relationship is concerned with another deeply entrenched problem: the damage caused by the conflict between different civilizations. The world's historical development is not always contingent on conflicts between civilizations, as is said by Huntington (1993). This conflict could also lead the world into disorder and chaos, especially when it comes to such unique

\footnotetext{
4 President Putin's Speech at the XI Session of the Valdai International Discussion Club. October 24th 2014. http://en.kremlin.ru/events/president/news/46860.

5 Matlock (2014).
} 
civilizations as Russia and the US. When Mr. Obama claimed the uniqueness of the US civilization, Mr. Putin responded by emphasizing the uniqueness of the "Russian world", which makes the balance between the universality and uniqueness featured in the world historical development hard to achieve.

Hence, seeking peaceful settlement is faced with great difficulty when there is cavernous division or even opposition towards the definition of the nation state, the idea of whether the post-Cold War international order is reasonable, whether there is understanding and respect shown between nations and the perception of the relationship between different civilizations.

\section{A Trinity Perspective: Legitimacy, Recognition of Historical Cultural Identity and Geopolitics}

The fundamental feature of the current international order is, on the one hand, that history is entering the second phase of the post-Cold War era. The biggest difference between the second phase and the 1989-1991 period resides in the fact that although America is still the only super power in the world, its capability in handling international affairs has been fundamentally shaken. A more diverse world is quickly emerging. On the other hand, the end of the Cold War did not follow the same route as other major changes that have taken place in international order. It is unlike Westphalia, Vienna, Versailles and Yalta, which all have clearly written international treaties, stipulating the interests and historical positions of both the vanquished nations and the victorious nations. However, the peaceful ending of the Cold War did not result in international treaties that set out each individual nation's international post-Cold War role clearly. These two phenomena have left people with no existing treaties and patterns to follow when it comes to resolving the Ukraine crisis.

Here it doesn't mean that the basic norms of international law could be disregarded. On the contrary, against current chaos in the world, international law plays a particularly important role. However, it calls for certain historic conditions regarding how to apply the complex system of international law under various concrete scenarios.

International conflicts such as the Ukraine and Syria crises can only be solved when sufficient consideration has been given to the following three aspects: domestic and international legitimacy, reasonable recognition of history and cultural identity and geopolitical competition. This trinity perspective is built on the following reasoning.

First of all, the three perspectives within the trinity cover all fundamental conditions and categories of international conflicts. The so-called "domestic and international legitimacy" perspective entails regulatory review of international law, domestic constitutionalism and common behavior law. It is legally binding and puts its emphasis on the "law of reason". The so-called recognition of history and cultural identity is a perspective that is based on fundamental facts, such as the causes of and reasons behind a certain event and its outcome. This perspective builds on the diversity and universality of people, which serves as a way to observe 
and understand all the existing events, morally, anthropologically and sociologically. Here, emphasis lies on the traceability of the fundamental facts and the "law of causality". The "geopolitical" perspective stems from the "natural status" of international political and economic capabilities, as is said by Hobbes (1651). Under this perspective, one needs to observe and identify the correlated ebb and flow of different forces and their spatial allocation, which includes a certain degree of measurability as well as taking into account the spontaneity of competition. Here, emphasis lies on the "law of nature".

Secondly, thinking only from one of the three perspectives would leave you not only unable to identify the complexities of international political situations, such as the Ukraine crisis, but also to find a solution. For example, from the legitimacy angle, despite the existence of certain rules and regulations, under extreme and emerging situations, having a full and comprehensive understanding of facts and evidence itself is difficult, not to mention the existence of many different wordings and applications of the law which are still widely open for interpretation, making it even harder to solve conflicts and disputes. Hence, settling complicated international disputes solely based on the interpretation of some articles in the law is not sufficient. Taking another example, the standpoint of the recognition of history and cultural identity is convincing in itself; however, historical and cultural situations can be very complex, especially when it comes to Ukraine, the intersection of different civilizations and complex cultures. It is hard to straighten out certain interests and the relationships between them. Thirdly, the angle of geopolitics is certainly the most straightforward and widely accepted traditional methodology in international politics. Thinking only from the perspective of rights, power and interests and taking them as the touchstone for identifying the truth is not entirely fair and justifiable (Zhang and Feng 2014).

Starting from here, in the writer's opinion, in dealing with the Ukraine and Syria crises, we make no claim of the non-existence of any touchstone whatsoever. However, it is also insufficient to act and react based on only one angle of the trinity perspective. It requires a rational, inclusive, comprehensive and balanced standpoint, as is explained above.

\section{European and Eurasian Security Frameworks under the Trinity Perspective}

The aforementioned trinity perspective can not only be applied to deal with crises that have already emerged, but also can be used to ponder over and explore future European and Eurasian security frameworks.

David Calleo, an expert on American and European affairs once said: the US, EU and Russia are shaping into a Tripartite Layout, where each one is separate and connected at the same time. In fact, this situation emerged earlier than the Cold War (David 2003). From the principles of the trinity perspective, for instance, from the "law of reason" that is concerned with legitimacy, Russia, Europe and US are three political entities that are protected by international law and domestic law to different degrees. From "the law of causality" that is concerned with history and culture, 
Russia, the US and Europe share the same origins but now stand independently on the international stage with their own uniqueness as a result of thousands of years of nurturing. From "the law of nature" that is concerned with geopolitical and economical competition, the US, Europe and Russia not only have their own systematic political, economical and security frameworks, but also have different degrees of clout and dominance in neighboring regions. It is without question that the US, Europe and Russia are geopolitically, economically and culturally independent from each other.

In terms of the dynamic between the US, Europe and Russia, does it follow the pattern of the widely expected "community of democracies in northern hemisphere", 6 with US as the dominant party and Russia as a supporting companion; or the "Great Europe", spearheaded by Europe with Russia as a partner (Sakwa 2015); or the "Great Eurasia" spearheaded by Russia with Europe as a partner; or the "Central Eurasia" that reinforces the Russia-China close strategic partnership with European cooperation (Karaganov and Bordachev 2015)? In this writer's opinion, in the first phase of the post-Cold War era, namely from the end of the 1980s to the early 1990s, if the possibility of a "community of democracies in northern hemisphere" did exist, reality overwhelmed it. Secondly, the "Europe-Russia alliance" Huntington predicted not only has failed to win US favor but also is out of accord with the context of the time, especially after the Ukraine and Syria crises. Besides, just as the EU would be reluctant to welcome Russia as a common member, Russia would be reluctant to accept the idea of joining in the first place. As far as the pattern of "Great Europe" is concerned, it has been applied for years from Lisbon to Vladivostok. However it is more of an example than a model to follow for the future. Thirdly, the pattern of "Central Eurasia" that reinforces the RussiaChina close strategic partnership with European cooperation, to some degree reflects the political trust and economic reality between China and Russia. Cooperation with Europe is also still on the negotiating table. However, from a long-term perspective, it calls for further pondering over issues like the US position and the future influence of various frameworks like TPP and TTIP. ${ }^{7}$

For the moment, even though we have intense situations as dire as Ukraine and Syria, this does not mean we will return to the all-out confrontation of the Cold War era. Russia shares close cultural and historical ties with Europe and they are highly mutually interdependent in terms of economic and security affairs. At least for the moment, the annual 400 billion USD of trade between Russia and Europe cannot be stopped immediately. And cultural and people-to-people contacts are even closer, like flesh and blood that cannot be severed from each other. In the meantime, the US and Russia need each other for nuclear disarmament, and even more so in terms of the global geopolitical and economic framework. Despite glaring opposition between Russia and the West in terms of the construction of important international and regional frameworks, they still could find a way out after the crisis dies down.

\footnotetext{
6 Brzezinski (2011).

7 In this regard, the author holds that Fu Ying's two articles express perfectly Chinese current views. Refer to: Fu Ying. September 9th 2015. How Chinese and Americans are Misreading Each Other-And Why It Matters, Huffington Post. http://www.huffingtonpost.com/fu-ying/chinese-americans-misread_b_ 8105040.html; Ying (2015).
} 
After the initiation of the Cold War, politicians both in Russia and in the US reflected profoundly on the Cold War. There is no reason that the political elites hoped this world would return to such all-out confrontation. Especially for those political elites,although they are estranged, they still focused on attacking the common enemy, namely terrorism, making advantages of their intelligent wisdom and wielding their power under international law. It can be imagined that those political elites were not doing so only for the sake of expanding their clout; but more importantly, to seek a solution out of the crisis despite the existence of many challenges.

In terms of China's attitude, it is probably still too early for us to make a comprehensive and systematic conclusion that is based on theory and conforms to China's reality. However, you can see how the Chinese have changed their thinking over time by reviewing a series of adjustments in their strategy and policy.

It is safe to say The Silk Road Economic Belt and the 21st-Century Maritime Silk Road Initiative (hereafter referred to as the Belt and Road Initiative, or B\&R Initiative) is a key area of China's foreign strategy. ${ }^{8}$ The B\&R Initiative, if defined as a "blueprint", may not reflect a series of actions undertaken right now; if defined as a complete "strategy", it still falls short of some targets that remain to be achieved through cooperation. For the moment, there is still great elasticity in the definition.

However, the $B \& R$ Initiative is indeed a vision resulting from many years' efforts in various circles. Firstly, for a long time, Western Europe and East Asia have been sitting at the two ends of the Eurasian continent. However, the area between them always finds itself baffled by challenges and obstacles with regards to both the natural environment and development opportunities. Therefore, the fundamental aim of this vision is to achieve overall development of Western Europe, East Asia and Eurasia as a whole through mutually beneficial cooperation. If Eurasia can not obtain more development opportunities, from a long-term perspective, this is no good to anyone. This is also why China, grateful of all the benefits it reaped from international cooperation after so many years of hard work, has decided to pay back, starting from its neighbors.

Secondly, the sticking point in determining whether the B\&R Initiative will succeed or not relies first on whether China is capable of sustaining its economic growth. In the international debate about China's economic slowdown, most players express confidence in China's future growth. President Xi Jinping said several times that as long as the Chinese economy can maintain 6.5-7 \% growth, China is very likely to double its GDP per capita compared to 2010, and triple that of 2000, which means overall GDP would reach as high as 17 trillion USD. Under this context, over the next 5 years, China is going to import 5 trillion US dollars worth of commodities, and invest as much as 500 billion US dollars. The number of outbound tourists will reach 500 million. ${ }^{9}$ China is willing to try its best to share

\footnotetext{
${ }^{8}$ Refer to: Vision and Actions on Jointly Building Silk Road Economic Belt and 21st-Century Maritime Silk Road. March 28th 2015. National Development and Reform Commission, Ministry of Foreign Affairs, and Ministry of Commerce of the People's Republic of China.

9 Jinping (2015).
} 
development opportunities and address challenges with everyone. It goes without saying that China's first task is to learn how to cooperate with neighboring countries especially Russia to realize these goals.

Thirdly, to implement the B\&R Initiative, it is important to make connections with the existing institutional structure in some regions. Take the Russia-China relationship as an example, the Russian and Chinese leaders are far-sighted and have already decided to make connections between the Eurasian Economic Union and the B\&R Initiative. This is an important political agenda. Although there is obvious difference between the Eurasian Economic Union, which has a wellestablished regulatory and institutional structure in place, and the B\&R Initiative, which is mainly a project-based mechanism, it will not hinder the cooperation between China and Russia, and between the B\&R Initiative and Eurasian Economic Union. For years, China has never halted the economic cooperation with the EU, North America and Eurasian Economic Union on the grounds that the regional institutional framework is confining and not inclusive in nature.

Fourthly, the seemingly project-driven $B \& R$ Initiative is in fact based on implementing a series of current and future institution structures. This includes not only the Asian Infrastructure Investment Bank (AIIB), the BRICs bank and other supporting financial institutions, but also a few multilateral institutions that are still in the experimental phase but are increasingly bearing fruit, such as the trilateral cooperation between China, Russia and Mongolia and the Chongqing-XinjiangEurope international railway, which serve as the underpinning of the whole scheme. Recently the Shanghai Cooperation Organization also joined the league to serve as a platform. Through a series of bilateral investment agreements, the establishment of international multilateral development zones in the border region, and potential free trade zones, connections with existing projects has been enabled. ${ }^{10}$

Finally, in the context of globalization coming to a standstill, and international geopolitical and economic cooperation and competition becoming increasingly regionally focused, the trilateral relationship requires our urgent attention on how to avoid conflicts between different regional cooperation mechanisms that are all based in the same region but carry different missions, to avoid crises emerging. Besides, a seasoned Indian scholar ${ }^{11}$ once said, with too many regional cooperation mechanisms in place, a political leader is unable to attend all summits, which will limit the diffusion of the benefits the regional cooperation mechanisms are supposed to bring. In this sense, especially for a late-comer such as China, it will be a long-term trend in the foreseeable future that through cooperation, China will study and understand its cooperation partners so as to achieve mutual benefits; while at the same time, it will keep on high alert to avoid conflicts in constructing cooperation mechanisms. For all kinds of cooperative regulations and institutional structures, the decision on whether or not to establish a mechanism boils down to real-time demands and possibilities for the future. In this light, it is a reasonable

\footnotetext{
${ }^{10}$ The Joint Statement of the Russian Federation and the People's Republic of China on cooperation in construction of conjugation of the Eurasian Economic Union and the Silk Road Economic Belt. May 8th 2015. http://kremlin.ru/supplement/4971.

${ }^{11}$ Refer to Speech delivered by Indira P. Ravindran at the 2015 annual meeting at the Centre for BRICS Studies, Fudan University.
} 
choice for China to push for solid advance in the project-based B\&R Initiative first and then follow through with readjustment based on demands in reality. For the moment, the Eurasian Economic Union is improving its institutional structure. All member states have been reaping substantial benefits from economic cooperation and an improved institutional mechanism is in place. Generally speaking, it fares well for China. Hence there is no reason for China to shake the grounds of a welloperating regional cooperation mechanism.

In short, China needs to value its current development opportunities and the relatively peaceful international environment, which were earned at a huge price. China should treasure a series of strategic partnerships established through years of hard work, especially the China-Russia relationship. It will be our long-term strategy to maintain this achievement and implement a fair, mutually beneficial, sustainable and independent peaceful foreign policy.

\section{References}

Brzezinski, Zbigniew K. 2011. Our Common Geopolitical Challenge. Center for Strategic and International Studies. http://csis.org/publication/our-common-geopolitical-challenge.

David, Calleo. 2003. The Future of Europe. Trans. Feng Shaolei et al., 374-390. Shanghai: Shanghai People's Publishing House.

Ying, Fu. 2015. How China Sees Russia. Foreign Affairs, December 14.

Hobbes, Thomas. 1651. Leviathan: or The Matter, Forme and Power of a Common Wealth Ecclesiastical and Civil.

Huntington, Samuel P. Summer 1993. The Clash of Civilizations? Foreign Affairs 72: 22-49.

Jinping, Xi. 2015. Towards a Community of Common Destiny and a New Future for Asia. Keynote speech at the Bo'ao Forum for Asia Annual Conference, March 28.

Karaganov, Sergei. 2011. Hotel Europe: Guests and Permanent Partners. Russia in Global Affairs 4: 172-180.

Karaganov, Sergei, and Timofey Bordachev. 2015. Creating Central Eurasia: the Silk Road Economic Belt and the Priorities of the Eurasian States' Joint Development. Journal for Russian Studies 3: 20-34.

Matlock Jr, Jack F. 2014. Who is the bully? The US has treated Russia like a loser since the end of the Cold War. Washington Post. https://www.washingtonpost.com/opinions/who-is-the-bully-theunited-states-has-treated-russia-like-a-loser-since-the-cold-war/2014/03/14/40868882-aa06-11e38599-ce7295b6851estory.html.

Sakwa, Richard. 2015. BRICS and the End of Greater Europe. Journal for Russian Studies 5: 97-110.

Zhang, Xin, and Shaolei Feng. 2014. A Theoretical Analysis of the Ukrainian Crisis. World Economics and Politics 6: 145-155.

Shaolei Feng is the Director of the Centre for Co-development with Neighboring Countries and the Center for Russian Studies at East China Normal University. He served as the Dean of the School of Advanced International and Area Studies at East China Normal University from 2004 to 2015, and is a member of the Valdai Club International Academic Board. Professor Feng is the author of almost 200 academic papers, and has authored and edited numerous books and led major international and national research projects. 